\title{
The Singapore Convention: A Solution in Search of a Problem?*
}

(pre-proof accepted version, Northern Ireland Legal Quarterly forthcoming)

\begin{abstract}
$\underline{\text { Abstract }}$
This paper explores the purpose and efficacy of the United Nations Convention on International Settlement Agreements Resulting from Mediation ('Singapore Convention' or 'Convention'). The Convention's genesis was premised on the notion of alleviating the enforceability issues that are annexed to settlement agreements arising from cross-border mediation (IMSA). While such enforceability issues are not entirely unfounded, the way in which the Convention has been drafted to address such issues has been the subject of criticism. In view of such criticism, this article explores the empirical research upon which the Convention's introduction is based and queries whether the structure of the instrument heralds an unnecessary juridification of the mediation process. In particular, a close review of the research highlights the unintended consequences that can flow from the Convention's uptake, suggesting that the introduction of the Convention may lead to an increase in issues pertaining to IMSA enforcement. It is in this context in which this article submits that the Convention may be regarded as a solution in search of a problem.
\end{abstract}

Key words: mediation; alternative dispute resolution (ADR); cross-border mediation; Singapore Convention; international commercial mediation; barriers to mediation; enforcement.

\footnotetext{
* Bryan Clark, Professor of Law and Civil Justice, Newcastle University Law School, UK; Tania Sourdin, Professor and Dean of Newcastle Law School, Australia
} 


\section{Introduction}

This article is concerned with the United Nations Convention on International Settlement Agreements Resulting from Mediation ('Singapore Convention' or 'Convention'), a multinational treaty with its origins in the U.N. Commission on International Trade Law ('UNCITRAL'). In short, the Singapore Convention introduces a new, uniform mechanism for the cross-border enforcement and recognition of settlement agreements rendered in international commercial mediations ('IMSAs'). In this sense, the Singapore Convention broadly mirrors and takes inspiration from the approach found in the New York Convention for the cross-border enforcement of arbitral awards in international commercial arbitration. ${ }^{1}$ Some four years in gestation, the Singapore Convention was adopted by the U.N. General Assembly on 20 December $2018^{2}$ and signed by 46 countries $^{3}$ in Singapore on 1 August 2019, although at the time of writing the number of signatories has climbed to 53. The Convention came into force on the $20^{\text {th }}$ September 2020, which occurred six months after deposit of the third instrument of ratification, acceptance, approval or accession ${ }^{4}$. Concurrently, amendments were also made to the Model Law on International Commercial Conciliation ('The Model Law') which can be adopted by States to help ease the Convention into their domestic systems. ${ }^{5}$ The Singapore Convention has been broadly welcomed by mediation organisations and

\footnotetext{
${ }^{1}$ UNCITRAL, 'Convention on the Recognition and Enforcement of Foreign Arbitral Awards' (10 June 1958) 330 UNTS 38.

2 See: UNGA, 'Report of the United Nations Commission on International Trade Law' (25 June - 13 July 2018) UN Doc A/73/17, 50-55.

${ }^{3}$ Including the USA and China. See generally: Penningtons Manches Cooper LLP, 'The Singapore Convention on Mediation: Could 2020 be the Year of the Ratification?' (Lexology, 22 January 2020) <https://www.lexology.com/library/detail.aspx?g=43578b07-7b21-4ba7-a229-a7f98ed0254d>accessed 16 June 2020.

4 UNICTRAL, 'United Nations Convention on International Settlement Agreements Resulting from Mediation' (20 December 2018) UN Doc A/Res73/198, article 14(1). Six states have ratified the Convention at the time of writing.

${ }^{5}$ United Nations, UNCITRAL Model Law on International Commercial Conciliation and Guide to Enactment and Use 2002 (United Nations 2004) 36-37, para 55.
} 
commentators alike as providing a useful 'shot in the arm' for international commercial mediation. ${ }^{6}$

Despite this enthusiasm, the terms of the Convention's drafting have not escaped academic and professional criticism. ${ }^{7}$ While in this article some facets of this critique are explored, the central task is to scrutinise the need for the Convention in the first place and to examine some of the potentially deleterious unintended consequences arising from its introduction. In short, the authors posit that the Convention could be regarded as a solution in search of a problem. It is thus argued that the premise behind the Convention's introduction is based both upon questionable empirical evidence as well as potential misapprehension of the nature of mediation by the uninitiated. Furthermore, while accepting that the Singapore Convention may provide greater publicity and enhanced legitimacy to international commercial mediation through its regulatory functions,${ }^{8}$ the authors caution that this new instrument may herald an unnecessary juridification of the process and lawyer domination therein that may paradoxically lead to greater enforcement problems with mediated outcomes, and militate against some key, qualitative benefits of the process. Other barriers to uptake are also explored as well as measures to help expedite acceptance and use of mediation in international commercial matters such as awareness raising, overcoming cultural and professional barriers and greater

\footnotetext{
${ }^{6}$ See for example: Eunice Chua, 'The Singapore Convention on Mediation - A Brighter Future for Asian Dispute Resolution' (2019) 9 Asian Journal of international Law 195; 'Singapore Convention Brings Big Changes for Litigators and Arbitrators' (JAMS, 5 August 2019) <https://www.jamsadr.com/blog/2019/singaporeconvention-brings-big-changes-for-litigators-and-arbitrators> accessed 15 June 2020; Haris Meidanis, 'International enforcement of mediated settlements: two and a half models - why and how to enforce internationally mediated settlement agreements' (2019) 85(1) Arbitration (London) 49.

7 See for example: Migle Zukauskaite, 'Enforcement of Mediated Settlement Agreements' (2019) 111 Teise 205, 211-214; Masood Ahmed, 'Reflections on the UNICTRAL Convention on the Enforcement of Mediation Settlement Agreements and Model Law' (2019) Lloyds Maritime and Commercial Law Quarterly 259.

8 Indeed, this is seen as especially important in some jurisdictions such as Asia, see generally: Gloria Lim, 'International Commercial Mediation: The Singapore Model' (2019) 31 SAcLJ 377.
} 
embedding within contracts that should not be forgotten in the rush to embrace the Singapore Convention.

The structure of this Article is as follows: first, the origins and nature of the Singapore Convention are mapped out with a brief examination of its main provisions; this is followed by an analysis of the evidence base behind the need for a uniform enforcement mechanism for IMSAs; and finally an examination is offered of some of the potential deleterious consequences arising from introduction of the Singapore Convention with a brief discussion of other barriers to uptake and strategies that may help expedite the greater use of international cross border mediation.

\section{Provisions of the Singapore Convention}

\subsection{Basic premise of the Convention}

The terms of the Convention were the subject of extensive negotiation and revision over its period of gestation. In this sense, the Convention is inevitably a product of compromise. ${ }^{9}$ Some of the consequences that this hard-fought bargaining had on the drafting of the Convention are discussed further below. It is first however worth noting that the Convention can be invoked as both a 'sword' and a 'shield'. In the former sense, it may be used as a way in which to enforce mediated outcomes and, in the latter sense, as a means of resisting legal action by another on the basis that the dispute has already been resolved. In this regard, Article 3(1) allows parties to instigate proceedings in signatory States to enforce the terms of the relevant

\footnotetext{
${ }^{9}$ See Timothy Schnabel, 'The Singapore Convention on Mediation: A Framework for the Cross-Border Recognition and Enforcement of Mediated Settlements' (2019) 19 Pepperdine Dispute Resolution Law Journal 1.
} 
IMSA. Article 3(2) by contrast, allows parties to invoke the terms of an IMSA in order to prove that a matter by which another party is seeking a remedy has already been resolved.

\subsection{Definitional Issues}

Article 1 provides that the Convention applies: 'to an agreement resulting from mediation and concluded in writing by parties to resolve a commercial dispute ("settlement agreement") which, at the time of its conclusion, is international...'. Article 1 goes on to tie the definition of 'international' to the settlement agreement (rather than the subject of the dispute). It provides that the agreement is international in that: '(a) At least two parties to the settlement agreement have their places of business in different States; or (b) The State in which the parties to the settlement agreement have their places of business is different from either (i) The State in which a substantial part of the obligations under the settlement agreement is performed; or (ii) The State which the subject matter of the settlement agreement is most closely connected'.

There is no attempt in the Convention to adopt the notion of a particular mediation 'seat'. The Convention provides for a form of direct enforcement in that a party to an IMSA can seek enforcement in any country it chooses with no need for a process of review in the country of origin. ${ }^{10}$ As has been noted, this model 'essentially delocalises from the enforcement process the place where the [IMSA] may have been reached....This has the extra value that it can be of use to the existing and increasing electronic mediation proceedings that parties in mediation expect to have, so as to design solutions not tied to a specific legal system'. ${ }^{11}$

\footnotetext{
${ }^{10}$ Haris Meidanis, 'International enforcement of mediated settlements: two and a half models - why and how to enforce internationally mediated settlement agreements' (2019) 85(1) Arbitration (London) 49, 53.

${ }^{11}$ Haris Meidanis, 'International enforcement of mediated settlements: two and a half models - why and how to enforce internationally mediated settlement agreements' (2019) 85(1) Arbitration (London) 49, 53.
} 
While the term 'commercial' is not defined in the Convention, reference can be made to the Model Law where the term is afforded a wide interpretation. ${ }^{12}$ Certain kinds of disputes are specifically excluded from the scope of the Convention. According to Article 1(2), the Convention does not apply to settlement agreements '(a) Concluded to resolve a dispute arising from transactions engaged in by one of the parties...for personal, family or household purposes; (b) Relating to family, inheritance or employment law.' Furthermore, Article 1(3)(a) provides that the Convention shall not apply to settlement agreements '(i) That have been approved by a court or concluded the course of proceedings before a court; and (ii) That are enforceable as a judgement in the State of the court.' Similarly, Article 1(3)(b) excludes 'Settlement agreements that have been recorded and enforceable as an arbitral award.' The narrowing of the Convention's reach in these regards has attracted some adverse commentary. For example, some commentators have noted that the exclusion of consumer and employment disputes is an opportunity lost to help expedite growth in these areas and that the carve outs, particularly around ISMAs otherwise enforceable in court regimes, are manifestly uncertain. ${ }^{13}$ This may in fact mean that some ISMAs fall through the gaps as not enforceable under the Singapore Convention but in practice will not be not enforceable through the Hague Convention either. ${ }^{14}$

The term 'mediation' is given a wide definition in the Singapore Convention to encapsulate a range of processes, irrespective of the domestic term used to describe them, in which 'parties attempt to reach an amicable settlement of their dispute with the assistance of a third person...

\footnotetext{
12 United Nations, UNCITRAL Model Law on International Commercial Conciliation and Guide to Enactment and Use 2002 (United Nations 2004) Article 1.

${ }^{13}$ See generally, for example: Migle Zukauskaite, 'Enforcement of Mediated Settlement Agreements' (2019) 111 Teise 205.

${ }^{14}$ The Hague Convention of 30 June 2005 on Choice of Court Agreements (concluded 30 June 2005) HCCH (The Hague). For a consideration of some of these issues see, for example: Migle Zukauskaite, 'Enforcement of Mediated Settlement Agreements' (2019) 111 Teise 205, 212.
} 
lacking the authority to impose a solution upon the parties... ${ }^{15}$ Such flexibility is also found in the requirement that the ISMA be recorded in writing. Under Article 2(2), this is defined as being recorded in 'any form', specifically encompassing an agreement found in 'electronic communication' such as email correspondence.

\subsection{Proof of IMSA}

A party seeking to rely on an IMSA must evidence its existence. Thus, the agreement must be signed by the parties. ${ }^{16}$ Evidence must also be provided that any agreement stemmed from mediation. This can be achieved in accordance with Article 4(1)(b) by either '(i) the mediator's signature on the settlement agreement; (ii) a document signed by the mediator indicating that the mediation was carried out; (iii) an attestation by the institution that administered the mediation; or (iv) in the absence of (i), (ii) or (iii), any other evidence acceptable to the competent authority.' Article 4(2) makes special provision meeting the requirements for signature in respect of electronic communication.

\subsection{Grounds of Relief}

A range of grounds under which an IMSA may be deemed unenforceable are included in the Convention under Article 5. It has been noted that while such exceptions should provide succour to States to ensure that settlements can be challenged in appropriate circumstances, the wide range of potential caveats may lead to significant post-mediation disputes regarding enforcement. ${ }^{17}$ As discussed later in this article, one of the dangers here is that such provisions

\footnotetext{
15 UNICTRAL, 'United Nations Convention on International Settlement Agreements Resulting from Mediation' (20 December 2018) UN Doc A/Res73/198, Article 2(3).

${ }^{16}$ UNICTRAL, 'United Nations Convention on International Settlement Agreements Resulting from Mediation' (20 December 2018) UN Doc A/Res73/198, Article 4(1)(a).

17 Migle Zukauskaite, 'Enforcement of Mediated Settlement Agreements' (2019) 111 Teise 205, 213; Masood Ahmed, 'Reflections on the UNICTRAL Convention on the Enforcement of Mediation Settlement Agreements and Model Law' (2019) Lloyds Maritime and Commercial Law Quarterly 259, 267-269.
} 
may in fact concentrate the mind of parties and their lawyers on the possibility of postsettlement challenges to enforcement. Clearly, such consequences are contrary to the aims of the Convention.

It is true that many of these grounds represent familiar territory and replicate those found in the New York Arbitration Convention. By dint of Article 5(1), these include: incapacity; when the agreement is null and void, inoperative, or incapable of being performed; that the agreement is not binding or not final according to its terms; has been subsequently modified; the obligations have been performed or are not clear or comprehensible; and that relief would be contrary to the terms of the settlement agreement. Under Article 5(2), exceptions are also provided for where granting relief would be contrary to the public policy or the subject matter is not capable of settlement by mediation of the competent authority.

Further grounds for refusing to grant relief pertain to circumstances in which there has been either a "serious breach of mediator standards"18 or 'a failure by the mediator to disclose to parties circumstances that raise justifiable doubts as to the mediator's impartiality or independence'. ${ }^{19}$ These provisions have received a mixed reception. As Meidanis has noted, these Articles 'have been criticised for dangerously extending the control of the MSA by the state of enforcement' ${ }^{20}$ One commentator has suggested that these grounds 'can be interpreted as a map for counsel to relieve its client of its obligations of a settlement agreement by focusing on the conduct of the mediator' and cautioned that attempts to unpick settlements on such bases

\footnotetext{
18 UNICTRAL, 'United Nations Convention on International Settlement Agreements Resulting from Mediation' (20 December 2018) UN Doc A/Res73/198, Article 5(e).

19 UNICTRAL, 'United Nations Convention on International Settlement Agreements Resulting from Mediation' (20 December 2018) UN Doc A/Res73/198, Article 5(f).

${ }^{20}$ Haris Meidanis, 'International enforcement of mediated settlements: two and a half models - why and how to enforce internationally mediated settlement agreements' (2019) 85(1) Arbitration (London) 49, 56.
} 
may erode mediation's important principles of confidentiality and evidential privilege. ${ }^{21}$ Others have played down such concerns on the basis that the use of these measures is limited to occasions in which parties must establish that, without the alleged serious breach of standards or failure to disclose circumstances laying doubt on impartiality or independence, the party concerned would not have entered into the mediation agreement. ${ }^{22}$ It is certainly the case that these provisions will raise questions around requirements for applicable mediator standards.

\subsection{Opt out/opt in}

A further controversial provision is Article 8 and, in particular, the fact that signatories may stipulate that the Convention shall apply 'only to the extent that the parties to the settlement agreement have agreed to the application of the Convention'. ${ }^{23}$ While this provision was required to accommodate the diverse views of delegates to the UNCITRAL Singapore Convention discussions, it has been criticised by some commentators. ${ }^{24}$ It has been argued operation of this provision may lead to an uneven application of the Convention and also afford the opportunity to more dominant parties to coerce their counter party to opt in to the terms of the Convention or otherwise to ensure that they can pursue the most advantageous approach to pursuing or resisting enforcement of the ISMA. ${ }^{25}$

\section{Why is the Convention needed?}

\footnotetext{
${ }^{21}$ F Peter Phillips, 'Concerns on the New Singapore Convention' (Mediate, October 2008) $<$ https://www.mediate.com/articles/phillips-concerns-singapore.cfm> accessed 15 June 2020.

22 See for example: Karl Mackie, 'Another Historic Step for Mediation' (Linkedln Pulse, 8 August 2019) <https://www.linkedin.com/pulse/another-historic-step-mediation-karl-mackie-cbe/> accessed 15 June 2020. 23 UNICTRAL, 'United Nations Convention on International Settlement Agreements Resulting from Mediation' (20 December 2018) UN Doc A/Res73/198, Article 8(1)(b).

24 Timothy Schnabel, 'The Singapore Convention on Mediation: A Framework for the Cross-Border Recognition and Enforcement of Mediated Settlements' (2019) 19 Pepperdine Dispute Resolution Law Journal 1, 56.

${ }^{25}$ See: Jan O'Neil, 'The new Singapore Convention: will it be the New York Convention for Mediation' (Thomson Reuters, Practical Law: Dispute Resolution Blog, 19 November 2018) $<$ http://disputeresolutionblog.practicallaw.com/the-new-singapore-convention-will-it-be-the-new-yorkconvention-for-mediation/> accessed 15 June 2020.
} 


\subsection{The perceived need}

The basis for the Singapore Convention's introduction is, as we will articulate below, well established. It can be argued, however, that principally the rationale emanates from a perception of failure. This failure, in particular, relates to the notion that commercial mediation has not made significant strides in the cross border context. ${ }^{26}$ This may seem particularly galling to mediation enthusiasts when set against the relatively strong growth of domestic commercial mediation found across a range of jurisdictions. ${ }^{27}$ In terms of explaining this disappointing state of affairs, for some time mediation providers and commentators in the field have expressed the idea that a major stifling factor to development of the process in the crossborder context has been the lack of any uniform enforcement mechanism for mediated agreements akin to that which operates in the field of international arbitration through the New York Convention. ${ }^{28}$ Indeed, views in favour of the desirability of a new uniform enforcement mechanism were aplenty in the inter-party UNCITRAL negotiations leading up to the adoption of the Singapore Convention. ${ }^{29}$

Mediation outcomes have historically been subject to quite varying treatment across different jurisdictions in terms of their enforcement. A range of possibilities exist including, most fundamentally, enforcement as contracts. Mere enforcement under general contract law brings

\footnotetext{
${ }^{26}$ See for example: International Institute for Conflict Prevention \& Resolution and Centre for Effective Dispute Resolution, 'Insights into Alternative Dispute Resolution' Winter 2018-19 1, 3 <https://www.cpradr.org/newspublications/reports/2019-04-04-cpr-cedr-joint-insights-report-on-the-use-ofadr/_res/id=Attachments/index=0/CEDR\%20CPR\%20report\%20040419.pdf> accessed 15 June 2020; Kim Shi Yin, 'From "Face-Saving" to "Cost Saving": Encouraging and Promoting Business Mediation in Asia' [2014] 32(10) Alternatives to the High Cost of Litigation 158, 158.

${ }^{27}$ For a review of developments see Neil Andrews, The Three Paths of Justice: Court Proceedings, Arbitration, and Mediation in England ( $2^{\text {nd }}$ edn, Springer 2018).

${ }^{28}$ David Weiss and Brian Hodgkinson, 'Adoptive Arbitration: An Alternative Approach to Enforcing CrossBorder Mediation Settlement Agreements' (2014) 25 American Review of International Arbitration 275; Lynn Cole, 'Exploring international Mediation' in Alexia Georgakopoulos (ed), The Mediation Handbook: Research, Theory, and Practice (Routledge, 2017) 318-319.

${ }^{29}$ For a review of these discussions see: Timothy Schnabel, 'The Singapore Convention on Mediation: A Framework for the Cross-Border Recognition and Enforcement of Mediated Settlements' (2019) 19 Pepperdine Dispute Resolution Law Journal 1, 3-4.
} 
with it, however, the uncertainties that can arise around conditions for enforcement and the general grounds for challenge such as fraud, misrepresentation, error and duress. ${ }^{30}$ As an improvement on this general situation, in some jurisdictions, outcomes rendered in mediation may be conferred a special enforcement status by the use of settlement deeds and notarised arrangements. In others, mediated settlements may by expressly approved by court. However, the situation is highly variable across different jurisdictions. ${ }^{31}$ As Zukauskaite notes, within the EU 'every country has a mechanism how to transform an [mediated settlement agreement] into a directly enforceable title'. ${ }^{32}$ However, '[o]utside the EU situation varies significantly..., ${ }^{33}$ with some countries having no means of transferring a mediated settlement into a directly enforceable title. ${ }^{34}$ While such measures may be generally considered adequate in respect of the enforcement of domestic mediated outcomes, the situation is more complex with regards to cross-border mediated agreements, with some of the delegates to the Convention negotiations highlighting such problems..$^{35}$

In light of the perceived problem in terms of enforceability of IMSAs, creative initiatives have been put in place to render mediated outcomes enforceable as 'consent awards' under the New York Convention through 'arb-med-arb' proceedings. ${ }^{36}$ Such approaches entail a dispute first

\footnotetext{
${ }^{30}$ For a discussion in the US context see: Edna Sussman, 'The Final Step: Issues in Enforcing the Mediation Settlement Agreement' (2008) The Fordham Papers 1, 7-16 <https://sussmanadr.com/docs/Enforcement_Fordham_82008.pdf> accessed 15 June 2020.

${ }^{31}$ For a review of different approaches see: Bobette Wolski, 'Enforcing Mediated Settlement Agreements: Critical Questions and Directions for Future Research' (2014) 7(1) Contemporary Asia Arbitration Journal 87, 93-99.

${ }^{32}$ Migle Zukauskaite, 'Enforcement of Mediated Settlement Agreements' (2019) 111 Teise 205, 207.

${ }^{33}$ Migle Zukauskaite, 'Enforcement of Mediated Settlement Agreements' (2019) 111 Teise 205, 207.

${ }^{34}$ Migle Zukauskaite, 'Enforcement of Mediated Settlement Agreements' (2019) 111 Teise 205, 208.

${ }^{35}$ See Timothy Schnabel, 'The Singapore Convention on Mediation: A Framework for the Cross-Border Recognition and Enforcement of Mediated Settlements' (2019) 19 Pepperdine Dispute Resolution Law Journal $1,3$.

${ }^{36}$ Including under the Singapore International Mediation Centre Protocol 2014, see for a discussion on the 'arb-med-arb' clause: 'The Singapore International Mediation Centre' (Singapore International Mediation Centre Insights, 2 November 2014) <http://simc.com.sg/blog/2014/11/02/singapore-international-mediationcentre/> accessed 16 June 2020.
} 
brought before an arbitral tribunal, with the arbitration then stayed immediately for mediation, and if a solution is brokered the matter is transferred back to the arbitration tribunal for recording as a consent award. Although there are varying views expressed as to whether consent awards are generally enforceable under the New York Convention for want of a dispute at the time the consent award is put in place by an arbitrator, ${ }^{37}$ it has been suggested that beginning the process in arbitration is sufficient to overcome these concerns by meeting the terms of the Article 1 of the New York Convention as applying to matters 'arising out of differences between persons' ${ }^{38}$ Even if such measures may be successful in a technical sense, the blending of mediation with arbitration in this way can lead to increased party costs and process complications which may limit their effectiveness. ${ }^{39}$ The potential harm arising from the infusing of mediation with more legal processes is a matter that we develop below. ${ }^{40}$

\subsection{Empirical studies}

A range of studies were undertaken in the lead up to the adoption of the Singapore Convention which, at first glance, lend succour to the notion that a unified international enforcement mechanism would be beneficial for future growth of international commercial mediation.

One of the principal studies that was conducted specifically to aid UNICITRAL's consideration of the new enforcement mechanism was that undertaken by Strong. ${ }^{41}$ Strong's work analysed

\footnotetext{
${ }^{37}$ See the discussion in Edna Sussman, 'The Final Step: Issues in Enforcing the Mediation Settlement Agreement' (2008) The Fordham Papers 1, 21-23 <https://sussmanadr.com/docs/Enforcement_Fordham_82008.pdf> accessed 15 June 2020.

${ }^{38}$ See Migle Zukauskaite, 'Enforcement of Mediated Settlement Agreements' (2019) 111 Teise 205, $209-210$.

${ }^{39}$ See for example: Bobette Wolski, 'Arb-Med-Arb (and MSAs): A Whole Which is Less Than, Not Greater Than The Sum of its Parts?' (2013) 6(2) Contemporary Asia Arbitration Journal 249.

${ }^{40}$ See 4.2.1. below.

${ }^{41}$ S Strong, 'Realizing Rationality: An Empirical Assessment of International Commercial Mediation' [2016] 73 Washington \& Lee Law Review 1973.
} 
survey responses from some 221 respondents drawn from a range of jurisdictions, including the USA, the UK, across Europe, Asia, Latin America, Oceania and the Middle East. ${ }^{42}$ Respondents included private practitioners, third party neutrals, academics, internal counsel and those in 'other forms of employment' including judges, government officials, those employed by arbitration institutions' ${ }^{43}$ Just over half of the respondents had been involved in at least one international commercial mediation over the three years preceding their completion of the survey with the remainder having had no such engagement in the previous three years. ${ }^{44}$ The survey asked respondents ${ }^{45}$ why parties might decline the use of international commercial mediation. Although concerns over the lack of enforceability of IMSA's was one of the issues listed in the survey, this was not included in the top five overall responses for either parties who had previous experience in international commercial mediation or those that did not. Strong explained: ${ }^{46}$

'[T]hose respondents who had been involved with at least one international commercial mediation within the previous three years chose the parties' lack of experience with mediation as the most likely reason why parties did not use that process in the international commercial context, with counsel's lack of experience with mediation coming in as the second most highly ranked option. This group of survey respondents also stated that concerns about revealing

\footnotetext{
42 S Strong, 'Realizing Rationality: An Empirical Assessment of International Commercial Mediation' [2016] 73 Washington \& Lee Law Review 1973, 2017.

43 S Strong, 'Realizing Rationality: An Empirical Assessment of International Commercial Mediation' [2016] 73 Washington \& Lee Law Review 1973, 2017.

44 S Strong, 'Realizing Rationality: An Empirical Assessment of International Commercial Mediation' [2016] 73 Washington \& Lee Law Review 1973, 2020. Although this was defined as 'including any matter for which the respondent had prepared, even if the mediation was cancelled before actual proceedings began', so it is possible that a proportion of this group did not in fact have actual experience of mediation.

45 This question was directed to all participants, regardless of whether they had participated in a commercial mediation before or not: S Strong, 'Realizing Rationality: An Empirical Assessment of International Commercial Mediation' [2016] 73 Washington \& Lee Law Review 1973, 2033.

${ }^{46}$ S Strong, 'Realizing Rationality: An Empirical Assessment of International Commercial Mediation' [2016] 73 Washington \& Lee Law Review 1973, 2034.
} 
litigation or arbitration strategy was the third most likely reason why parties would avoid mediation in international commercial disputes, with concerns about finding an effective mediator coming in as the fourth most popular option.'

For those without previous international commercial mediation experience, the most popular responses were a cultural preference for litigation or arbitration. ${ }^{47}$ Beyond that it is not clear from the survey data what those without experience in international commercial mediation believe are important factors as to why parties do not use the process. ${ }^{48}$ Overall, the data here is far from conclusive as to why parties decline the use of international commercial mediation. Further questions were asked of those both with and without previous experience about what might encourage the further use of international commercial mediation. For both those with experience and those without, the top three responses were having more evidence of the effectiveness of mediation, better information about the conduct of mediation and better information about the costs of mediation. ${ }^{49}$

Strong's survey also asked respondents directly about the desirability of an international convention on enforcement of IMSAs. Some $74 \%$ of respondents viewed that such a development would encourage parties in their own jurisdiction to make use of international commercial mediation and many of the free text comments are supportive of the potential benefits of such an instrument. ${ }^{50}$ It is interesting that this idea only really emerged, however,

\footnotetext{
${ }^{47}$ S Strong, 'Realizing Rationality: An Empirical Assessment of International Commercial Mediation' [2016] 73 Washington \& Lee Law Review 1973.

48 S Strong, 'Realizing Rationality: An Empirical Assessment of International Commercial Mediation' [2016] 73 Washington \& Lee Law Review 1973, 2035.

49 S Strong, 'Realizing Rationality: An Empirical Assessment of International Commercial Mediation' [2016] 73 Washington \& Lee Law Review 1973, 2037-2039.

${ }^{50}$ S Strong, 'Realizing Rationality: An Empirical Assessment of International Commercial Mediation' [2016] 73 Washington \& Lee Law Review 1973, 2055.
} 
when prompted by a direct question. However, the idea that a uniform enforcement mechanism for IMSAs would amount to a boon for international commercial mediation is found in other empirical research. A study conducted by Weiss and Griffiths for the International Mediation ('IMI') on the desirability of a uniform enforcement mechanism for the IMSAs ${ }^{51}$ analysed the views of 103 'users' of commercial mediation drawn from a range of different jurisdictions. ${ }^{52}$ Respondents were asked why they believed parties did not attempt to resolve their cross-border disputes through mediation. Of the four options which participants were asked to rank ('they are unfamiliar with mediation'; 'they had a bad experience previously with mediation'; 'they had a bad experience previously with arbitration'; and 'there is no universal mechanism to enforce a mediated settlement'), the most popular response was that of unfamiliarity and the second was the lack of an enforcement mechanism. ${ }^{53}$ It cannot be said that these responses are especially informative, however given the very limited range of options that was offered. Moreover, the option relating to negative past experiences with arbitration seems odd in this context and was unlikely to be popular.

However, when more direct questions regarding enforcement mechanisms were asked, uniformity in participants' responses began to emerge. In response to the question 'Would you be more likely to include a [contractual] mediation clause, if there were a uniform global mechanism to enforce mediation settlements i.e. similar to the 1958 Convention on the

\footnotetext{
${ }^{51}$ David Weiss and Michael Griffiths, 'Report on International Mediation and Enforcement Mechanisms' (Institute for Dispute Resolution IDR (NJCU) School of Business, UNCITRAL Working Group II (Dispute Settlement) 2017).

52 The term 'user' is not defined except that it is said to represent 'various field[s] and profession[s[ such as law, construction, energy, architecture, international business, healthcare, food and beverage service, water and waste management, tourism, trading, education, and finance': David Weiss and Michael Griffiths, 'Report on International Mediation and Enforcement Mechanisms' (Institute for Dispute Resolution IDR (NJCU) School of Business, UNCITRAL Working Group II (Dispute Settlement) 2017) 7, 9.

${ }^{53}$ Ib David Weiss and Michael Griffiths, 'Report on International Mediation and Enforcement Mechanisms' (Institute for Dispute Resolution IDR (NJCU) School of Business, UNCITRAL Working Group II (Dispute Settlement) 2017) 11-12.
} 

of respondents answered in the affirmative. ${ }^{54}$ Similarly, in response to the question, 'Would you be more likely to use or increase your use of mediation in a cross border dispute with another party or multiple parties of different jurisdictions if a uniform global mechanism was in place similar to the New York Convention to enforce a settlement agreement reached in the mediation process?', $84 \%$ of respondents indicated 'more likely' ${ }^{55}$ The authors also point to similar findings in the Global Pound Conference Series research. ${ }^{56}$ In the study, the majority of participants indicated from a set number of options that 'legislation or conventions that promote recognition and enforcement of settlements, including those reached in mediation' was the area 'most likely to improve commercial dispute resolution'. 57

To what extent such responses were given by potential users, legal advisors or others involved in the field, however, is not apparent from the Global Pound Conference report. ${ }^{58}$ Moreover, when the data is broken down by region, some stark differences in views regarding the utility of such legislative intervention is apparent. While legislation promoting the recognition and enforcement of mediated settlements receives a $64 \%$ rating from Asia and 61\% from Latin

\footnotetext{
${ }^{54}$ David Weiss and Michael Griffiths, 'Report on International Mediation and Enforcement Mechanisms' (Institute for Dispute Resolution IDR (NJCU) School of Business, UNCITRAL Working Group II (Dispute Settlement) 2017) 14.

55 David Weiss and Michael Griffiths, 'Report on International Mediation and Enforcement Mechanisms' (Institute for Dispute Resolution IDR (NJCU) School of Business, UNCITRAL Working Group II (Dispute Settlement) 2017) 16.

${ }^{56}$ Herbert Smith Freehills and PWC, 'Global Pound Conference Series: Global Trends and Regional Differences' (Global Pound Conference Series, 2018).

${ }^{57}$ David Weiss and Michael Griffiths, 'Report on International Mediation and Enforcement Mechanisms' (Institute for Dispute Resolution IDR (NJCU) School of Business, UNCITRAL Working Group II (Dispute Settlement) 2017) 23; Herbert Smith Freehills and PWC, 'Global Pound Conference Series: Global Trends and Regional Differences' (Global Pound Conference Series, 2018) 14 where the second top answer was 'protocols promoting non-adjudicative processes' (47\%) followed by 'cost sanctions' (36\%).

${ }^{58}$ The five stakeholder groups in the study were '1) Parties: end-users of dispute resolution, generally in-house counsel and business executives; 2) Advisors: private practice lawyers and other external consultants; 3 )

Adjudicative Providers: judges, arbitrators and their supporting organisations; 4 ) Non-adjudicative providers: mediators, conciliators and their supporting institutions; 5) Influencers: academics, government officers, policy makers': Herbert Smith Freehills and PWC, 'Global Pound Conference Series: Global Trends and Regional Differences' (Global Pound Conference Series, 2018) 6.
} 
America, the percentage drops significantly for other regions such as Oceania (37\%) and UK $(41 \%){ }^{59}$

Finally, a recent survey ${ }^{60}$ on cross border disputes was conducted by the Singapore International Dispute Resolution Academy ('SIDRA') of more than 300 international corporate executives, internal counsel and external counsel. ${ }^{61}$ The survey found that international commercial arbitration remained the most popular dispute resolution choice amongst respondents, followed by international commercial litigation, hybrid processes (arbitration and mediation combinations) and then mediation. ${ }^{62}$ These findings accord with perceptions of the dominance of arbitration and the relative light use of mediation in international commercial matters.

In terms of what factors drove respondents' preferences, the top ranked responses were enforceability, neutrality/impartiality, and cost. ${ }^{63}$ The perceived lack of enforceability in respect of ISMAs may hence contribute to the lowly status of mediation's popularity relative

\footnotetext{
${ }^{59}$ Herbert Smith Freehills and PWC, 'Global Pound Conference Series: Global Trends and Regional Differences' (Global Pound Conference Series, 2018) 20.

60 Singapore International Dispute Resolution Academy, 'International Dispute Resolution Survey: Currents of Change' (Preliminary Report, 2019)

<https://sidra.smu.edu.sg/sites/sidra.smu.edu.sg/files/documents/SIDRA2019_IDR_Survey_Preliminary_Repor t.pdf $>$ accessed 15 June 2020.

${ }^{61}$ In terms of breakdown the study surveyed 194 'corporate users' (executives and in-house counsel) and 110 external counsel who had been involved in international commercial disputes between 2016 and 2018 from a range of jurisdictions, with around half of the respondents drawn from Asia: Singapore International Dispute Resolution Academy, 'International Dispute Resolution Survey: Currents of Change' (Preliminary Report, 2019) 3

<https://sidra.smu.edu.sg/sites/sidra.smu.edu.sg/files/documents/SIDRA2019_IDR_Survey_Preliminary_Repor t.pdf $>$ accessed 15 June 2020.

62 Singapore International Dispute Resolution Academy, 'International Dispute Resolution Survey: Currents of Change' (Preliminary Report, 2019) 4

<https://sidra.smu.edu.sg/sites/sidra.smu.edu.sg/files/documents/SIDRA2019_IDR_Survey_Preliminary_Repor t.pdf> accessed 15 June 2020.

63 Singapore International Dispute Resolution Academy, 'International Dispute Resolution Survey: Currents of Change' (Preliminary Report, 2019) 4

<https://sidra.smu.edu.sg/sites/sidra.smu.edu.sg/files/documents/SIDRA2019_IDR_Survey_Preliminary_Repor t.pdf $>$ accessed 15 June 2020.
} 
to other processes. The SIDRA survey then examined specific responses of survey participants in relation to international commercial mediation. In this sense it is unclear as to how much experience respondents actually had with international commercial mediation. The most common reasons for selecting mediation were noted as 'impartiality of the forum', 'confidentiality' and 'speed' ${ }^{64}$ The authors note that '[un]like users of arbitration, mediation users do not rank enforceability very highly on their list of reasons to mediate ${ }^{65}$ attributing this view to a the lack of an internationally recognised, expedited enforcement mechanism for mediation. Thus, it is suggested that 'where compliance with the outcome of a dispute resolution process is a concern and enforcement mechanisms are a priority, mediation is less likely to be selected'. ${ }^{66}$ The circularity in thinking evident here ignores the fact that participation in mediation may itself be enough to dispel the myth that post-mediation settlement enforcement is likely to be a problem. It is to this issue that we now turn.

\subsection{Is the problem a real one?}

Although the evidence is far from conclusive, the empirical research discussed above suggests there may be some demand from users, potential users, their advisors, commentators as well as current and putative mediation providers for the kind of uniform enforcement mechanism created by the Singapore Convention. Nonetheless, these studies at times suffer from a lack of precision as to who is making such claims. It is not always clear whether the views expressed

\footnotetext{
${ }^{64}$ Singapore International Dispute Resolution Academy, 'International Dispute Resolution Survey: Currents of Change' (Preliminary Report, 2019) 15

<https://sidra.smu.edu.sg/sites/sidra.smu.edu.sg/files/documents/SIDRA2019_IDR_Survey_Preliminary_Repor t.pdf> accessed 15 June 2020.

65 Singapore International Dispute Resolution Academy, 'International Dispute Resolution Survey: Currents of Change' (Preliminary Report, 2019) 15

<https://sidra.smu.edu.sg/sites/sidra.smu.edu.sg/files/documents/SIDRA2019_IDR_Survey_Preliminary_Repor t.pdf> accessed 15 June 2020.

${ }^{66}$ Singapore International Dispute Resolution Academy, 'International Dispute Resolution Survey: Currents of Change' (Preliminary Report, 2019) 15

<https://sidra.smu.edu.sg/sites/sidra.smu.edu.sg/files/documents/SIDRA2019_IDR_Survey_Preliminary_Repor t.pdf> accessed 15 June 2020.
} 
are those of external lawyers, inside counsel, corporate clients, mediation providers or other commentators. Equally it is not always apparent when such views expressed represent actual practical experiences in mediation or are merely observations. There may also be some distinct regional variations with some studies, for example, the SIDR research, skewed towards Asia where the desire for formal regulation in the field may be culturally stronger.

In the international commercial context, there seems at best limited evidence that IMSAs are in fact not adhered to by the parties that crafted them. ${ }^{67}$ The bulk of commentators accord with this view. ${ }^{68}$ Although in the deliberations leading up to the Convention some delegates alluded to instances where settlement agreements had required cross border enforcement proceedings, ${ }^{69}$ as Schnabel notes the main goal of the Convention is 'to provide an incentive to mediate in the many cases in which mediation might otherwise not be attempted. Ideally the Convention will rarely need to be invoked in court, as in most cases, parties will abide by the mediated settlements they conclude'. ${ }^{70}$ Commercial settlements are generally undergirded with

\footnotetext{
${ }^{67}$ A 2015 study into international arbitration (which also touched upon mediation) found only 8\% of respondents stating that they had experienced difficulties in enforcing ISMAs in the previous 5 years: White \& Case, '2015 International Arbitration Survey: Improvement and Innovations in International Arbitration' (School of International Arbitration, Queen Mary University of London, 2015) <http://www.arbitration.qmul.ac.uk/media/arbitration/docs/2015_International_Arbitration_Survey.pdf> accessed 15 June 2020.

${ }^{68}$ As noted by Masood Ahmed, 'Reflections on the UNICTRAL Convention on the Enforcement of Mediation Settlement Agreements and Model Law' (2019) Lloyds Maritime and Commercial Law Quarterly 259, 261: '[s]ettlement agreements resulting from mediation are more likely to be adhered to voluntarily'. Similarly Mackie suggests that 'few mediated settlement agreements fail to be implemented in the first place...': Karl Mackie, 'Another Historic Step for Mediation' (Linkedln Pulse, 8 August 2019) <https://www.linkedin.com/pulse/another-historic-step-mediation-karl-mackie-cbe/> accessed 15 June 2020. ${ }^{69}$ See: Intervention of Corporate Counsel International Arbitration Group (CCIAG), in UNICTRAL Audio Recordings: Working Group II (Arbitration and Conciliation, $62^{\text {nd }}$ Session, 3 February 2015), cited in Timothy Schnabel, 'The Singapore Convention on Mediation: A Framework for the Cross-Border Recognition and Enforcement of Mediated Settlements' (2019) 19 Pepperdine Dispute Resolution Law Journal 1, 4. 70 Timothy Schnabel, 'The Singapore Convention on Mediation: A Framework for the Cross-Border Recognition and Enforcement of Mediated Settlements' (2019) 19 Pepperdine Dispute Resolution Law Journal 1, 4 (internal citations omitted).
} 
a "a 'belt and braces' use of securities, guarantees and asset-backed obligations" to render them self-enforcing. ${ }^{71}$

Nonetheless, in terms of why endeavours to avoid compliance might take place, as one commentator put it: '[b]uyer's remorse, changing conditions over the course of the agreement's execution and other factors routinely can lead to parties to any negotiated settlement reneging their promise to execute'. ${ }^{72}$ The study by Weiss and Griffiths did find some evidence of participants requiring at times to resort to litigation in respect of mediated settlements which had not been adhered to ${ }^{73}$ However, the basis for this proposition is weak. ${ }^{74}$ It has also been noted by Nolan-Haley ${ }^{75}$ in the US context that the highest number of litigated mediation cases (in recent years) concerned challenges to the enforceability of mediated agreements and that generally challenges to mediated outcomes are on the rise. The US evidence may be skewed, however, by the increasing rise of court-based mandatory mediation in which recalcitrant parties, unwilling to attend mediation, may be more prone to trying to extricate themselves from mediated outcomes. Equally, Nolan-Haley suggests that part of the reason for this increase in challenges to mediated outcomes may be linked to the fact that 'in some contexts, the practice of mediation is becoming very much like the practice of traditional arbitration or like a judicial settlement conference' thus leading to greater prospect for parties to seek to

\footnotetext{
71 James Maxey, "Singapore Convention heralds new era for international mediation or is it a false dawn?" < https://www.buckles-law.co.uk/blog/singapore convention heralds new era international mediation/> accessed 21 October 2010.

${ }^{72}$ Gary Birnberg, 'Singapore Convention Brings Big Changes for Litigators and Arbitrators' (JAMS ADR Blog, 2019) 2 <https://www.jamsadr.com/blog/2019/singapore-convention-brings-big-changes-for-litigators-andarbitrators > accessed 15 June 2020.

73 David Weiss and Michael Griffiths, 'Report on International Mediation and Enforcement Mechanisms' (Institute for Dispute Resolution IDR (NJCU) School of Business, UNCITRAL Working Group II (Dispute Settlement) 2017) 20-21 in which it was reported that of 92 respondents who answered this question 35\% indicated that they infrequently had to relitigate mediated settlements that were not honoured with $8 \%$ indicating that they frequently had to do so..

74 The small numbers involved here and doubts around the extent that these respondents were speaking from significant experience mean that these findings should be treated with caution.

75 Jacqueline Nolan-Haley, 'Judicial Review of Mediated Settlements: Improving Mediation with Consent?' (2013) 5 Arbitration Law Review 152.
} 
unravel agreements. ${ }^{76}$ This is important. Such trends, insofar as they currently exist, may in fact accelerate as a consequence of the increased juridification of mediation likely to occur in the aftermath of the Singapore Convention. The authors return to this point below. ${ }^{77}$

It may be contended that uninitiated users or advisors participating in the surveys above are at times conflating their own experiences in arbitration with the promise of mediation. In arbitral proceedings it is the case of course that awards are imposed on parties. It may hence be natural that one party is unhappy and seeks to find ways of avoiding complying with its terms. Thus, against this backdrop, the New York Convention facilitating easier cross-border enforcement is an important measure in ensuring enforcement and this backstop provides users with the confidence that the process will de facto be binding. In mediation, however, the parties are not bound to make agreements and any such outcomes crafted are done so by the parties voluntarily. As has been widely noted, this is likely to lead to increasing 'ownership' of outcomes rendered and the fact that mediated agreements are hence largely adhered to by parties without further enforcement activity has been proven to be the case in a range of contexts. ${ }^{78}$ Other barriers to mediation's uptake are at play. These are discussed below. ${ }^{79}$

\section{Might the Convention be counterproductive?}

\subsection{Profile Raising}

It could be argued that even if the problem that the Singapore Convention seeks to tackle is largely illusory, it will do no harm and that the existence of the right to enforce outcomes will

\footnotetext{
${ }^{76}$ Jacqueline Nolan-Haley, 'Judicial Review of Mediated Settlements: Improving Mediation with Consent?' (2013) 5 Arbitration Law Review 152, 153.

77 See 4.2.1. below.

${ }^{78}$ See, for example: Craig McEwen and Richard Maiman, 'Mediation in Small Claims Court: Achieving Compliance Through Consent' (1981) 18(1) Law and Society Review 11; Roselle Wissler, 'The Effectiveness of Court-Connected Dispute Resolution in Civil Cases' (2004) 22 Conflict Resolution Quarterly 55, 65-68. Although as the authors have already noted, increased lawyer domination of mediation may counter these effects.

${ }^{79}$ See 5.1. below.
} 
provide confidence to users. ${ }^{80}$ Moreover, the resultant profile raising of the international commercial mediation process shall significantly benefit its development. There is clearly some truth in this proposition. The profile of international commercial mediation has never been higher. There has been a glut of writing on the subject. Moreover, national and international conferences and webinars analysing the impact of the Singapore Convention are aplenty. ${ }^{81}$

The desire to adopt the Singapore Convention may be more pronounced in some jurisdictions than in others. As we noted above, the Global Pound Conference data suggested a greater preference for a uniform, ISMA enforcement regime in some jurisdictions such as Asia and Latin America than in others, like Oceania and the UK. More generally there may be more of a recognition culturally for increased regulation and formality as a proxy for legitimacy in some jurisdictions. ${ }^{82}$ The Singapore Convention certainly responds to that audience.

\subsection{Operational Difficulties}

Some immediate problems spring to mind, however. At a basic level of acceptance, some major players such as the EU, the UK and Australia have not yet signed up to the Singapore Convention and could thus serve to stifle the aspirations of enthusiasts.

\subsubsection{Wide scope of relief}

\footnotetext{
${ }^{80}$ Veronika Vanisova, 'Current Issues in international Commercial Mediation: Short Note on the Nature of Agreement Resulting from Mediation in Light of the Singapore Convention' (2019) Charles University in Prague Faculty of Law Research Paper No 2019/11/5.

${ }^{81}$ See, for example: 'Singapore Convention Seminar Series' (Immediation) <https://www.imimediation.org/2020/03/27/singapore-convention-online-seminar-series-the-line-up/> accessed 15 June 2020.

82 See, for example, Gloria Lim, 'International Commercial Mediation: The Singapore Model' (2019) 31 SAcLJ 377,381 para 12 where it was noted that regulation in ADR and mediation in particular, reflected aspects of Asian tradition and culture.
} 
Moreover, drafting issues may also have negative impacts. For example, as we noted above, ${ }^{83}$ it can be argued that the scope afforded for potential challenges to settlements under the Convention is wide. In terms of the grounds for refusal to grant relief, their expansive nature has led to criticisms that this might lead to an undermining of the Convention. Some commentators, for example, have argued that excessive challenges may serve to counter important characteristics of mediation like confidentiality and evidential privilege. ${ }^{84}$ Indeed, the authors argue that the mere existence of the Convention may per se lead to a greater ex post scrutiny of mediated outcomes and more attempts by parties to extricate themselves from outcomes rendered.

\subsubsection{The Singapore Convention and creative settlements}

One of the grounds under Article 5 by which a court or competent authority may refuse to grant relief is where an outcome is 'not clear or comprehensible'. ${ }^{85}$ One significant potential benefit of mediation lies in the possibility of creative agreements. ${ }^{86}$ By this we mean settlements beyond the gift of courts or common products of bilateral negotiations that can meet parties' underlying interests in a meaningful fashion. So, this kind of outcome could provide a framework for parties' future business conduct, including exploration of business interests and apologies tendered by one party to the other. However, not all such outcomes may be capable of being rendered in a definitive, legally robust fashion, and in this way may fall foul of the 'clear and comprehensible' exception. ${ }^{87}$ As Phillips has stated: 'settlements (where mediated

\footnotetext{
${ }^{83}$ See 2.4. above.

${ }^{84}$ F Peter Phillips, 'Concerns on the New Singapore Convention' (Mediate, October 2008)

$<$ https://www.mediate.com/articles/phillips-concerns-singapore.cfm> accessed 15 June 2020.

85 UNICTRAL, 'United Nations Convention on International Settlement Agreements Resulting from Mediation' (20 December 2018) UN Doc A/Res73/198, Article 5(1)(c)(i).

${ }^{86}$ See in the Scandinavian context: Lin Adrian and Solfrid Mykland, 'Creativity in Court-Connected Mediation: Myth or Reality' (2014) 30(4) Negotiation Journal 421.

87 UNICTRAL, 'United Nations Convention on International Settlement Agreements Resulting from Mediation' (20 December 2018) UN Doc A/Res73/198, Article 5(1)(c)(i).
} 
or not) result in agreements, with mutual obligations whose authority derives from the parties' consent, and often they are incapable on their face of being merely "enforced"”. 88

Although it has been said that mediation's potential for creative settlements has been overstated, ${ }^{89}$ a decline in this regard may be attributed to the rise of 'legal mediation' involving evaluative mediation practice and adversarial lawyering, leading to the narrowing of focus on legal matters and monetary settlements. ${ }^{90}$ This trend may well continue in the post-Singapore Convention era with parties increasingly focusing on producing watertight, legally-binding outcomes, especially when the existence of the Convention itself raises the issue of potential non-compliance more squarely into the parties' minds at the time of settlement formation.

\subsection{The further juridification of mediation}

Despite the generally flexible approach of the Convention the authors contend that it may nonetheless change the underlying nature of international commercial mediation to render it the more natural terrain of the law and lawyers.. There is a heightened role for lawyers anticipated by the Convention around for example, providing for requisite formalities in, and ensuring legally certain IMSAs, anticipating how agreements brokered may fare in different jurisdictions in which enforcement may be sought and navigating the grounds for challenges to enforcement. As Mackie has noted, '[the Convention] is a win-win for mediators and lawyers. On the one hand, mediation now has further legitimacy in international trade rules. On the other, lawyers have an additional legal instrument on which they can advise or seek

\footnotetext{
${ }^{88}$ F Peter Phillips, 'Concerns on the New Singapore Convention' (Mediate, October 2008) $<$ https://www.mediate.com/articles/phillips-concerns-singapore.cfm> accessed 15 June 2020. ${ }^{89}$ See, for example: Nancy Welsh, 'Making Deals in Court-Connected Mediation: What's Justice Got to Do with It?' (2001) 79 Washington Law Quarterly 787, 813-816.

${ }^{90}$ See Jacqueline Nolan-Haley, 'Mediation: The 'New Arbitration” (2012) 17 Harvard Negotiation Review 1.
} 
grounds to argue on behalf of clients'. ${ }^{91}$ The idea that the Convention is a 'win' for lawyers is worrying. Any increasing role for lawyers in and around mediation should be viewed with caution. In this sense, much of the current debate around the increasing complexity and cost of international commercial arbitration is centred on the role of lawyers in the process. ${ }^{92}$ Flood and Caiger tracked the growing historical development of the role of the lawyer and the law in commercial arbitration and the ensuing morphing of the process from a flexible, quick and business-friendly process to one which mimics formal legal process in many respects. ${ }^{93}$ Similarly, Nolan-Haley laments the time when it was 'unnecessary to employ legal sanctions for compliance with arbitral awards because community members relied on each other's good faith' but that this no longer holds in an era in which 'arbitration was transformed into a more coercive and legalistic process'. ${ }^{94}$

The same charge has already been levelled at mediation. ${ }^{95}$ Lawyers are, of course, important players in mediation. Their presence is often valued by mediators and their assistance in articulating claims, negotiating with an opponent and even protecting against mediator pressure is sought out by their clients. ${ }^{96}$ The increasing domination of lawyers in the mediation process has, however, led to resultant rising costs, complexity and a narrowing of bargaining so that there may be a greater focus on rights rather than interests. In a damning critique of the

\footnotetext{
${ }^{91}$ Karl Mackie, 'Another Historic Step for Mediation' (Linkedln Pulse, 8 August 2019) <https://www.linkedin.com/pulse/another-historic-step-mediation-karl-mackie-cbe/> accessed 15 June 2020 (our emphasis).

92 See Steven Seidenberg, 'International Arbitration Loses its Grip' (2010) 96 ABAJ 50, 55.

93 John Flood and Andrew Caiger, 'The Juridification of Arbitration: The Juridification of Construction Disputes' (1993) 56 The Modern Law Review <https://papers.ssrn.com/sol3/papers.cfm?abstract_id=3395051> accessed 16 June 2020. The dominance of lawyers as arbitrators is now a well-recognised phenomenon, see for example: Thomas Stipanowich \& Zachary Ulrich, 'Arbitration in Evolution: Current Practices and Perspectives of Experienced Commercial Arbitrators' (2014) 25 Columbia American Review of International Arbitration 395, 404-405.

94 Jacqueline Nolan-Haley, 'Mediation: The 'New Arbitration” (2012) 17 Harvard Negotiation Review 1, 87-88.

95 Jacqueline Nolan-Haley, 'Mediation: The 'New Arbitration” (2012) 17 Harvard Negotiation Review 1, 87-88.

${ }^{96}$ Kathy Douglas and Becku Batagol, 'The Role of Lawyers in Mediation: Insights from Mediators a Victoria's Civil and Administrative Tribunal' (2014) 40 Monash University Law Review 757, 784-785.
} 
increasing legalisation of mediation in the US context, Nolan-Haley goes so far as to say that '[1]awyers generally control the mediation process, considering it the functional equivalent of a private judicial settlement conference'. ${ }^{97}$ She also recounts the rise in evaluative mediators (often lawyers) behaving akin to arbitrators which has led to an increase in questionable unethical, adversarial lawyering and mediator 'spinning' by legal representatives in an attempt to influence such evaluations. ${ }^{98}$ Moreover, research by Stipanowich in the context of district court mediation found that the offering of solutions or opinions by mediators had a long term negative impact on participants' views as to satisfaction with these outcomes. ${ }^{99}$ In a separate study he also found that mediators often felt 'bounced' into evaluation by lawyers. ${ }^{100}$ In the Australian setting, Corbin, Baron and Gutman have argued that there are still a number of lawyers who, within mediation, reject or at least find it hard to focus on client interests, sustaining relationships, and crafting solutions not centred on legal rights. ${ }^{101}$ This view is supported by Rundell's research into court connected mediation in the Supreme Court of Tasmania finding that lawyers often held a preference for pursuing outcomes based on legal norms. ${ }^{102}$ It has also been found that lawyers may adversely influence the ability of parties in mediation to reconcile with each other. ${ }^{103}$

\footnotetext{
97 Jacqueline Nolan-Haley, 'Mediation: The “New Arbitration” (2012) 17 Harvard Negotiation Review 1, 61.

98 Jacqueline Nolan-Haley, 'Mediation: The 'New Arbitration”' (2012) 17 Harvard Negotiation Review 1, 83.

99 State Justice Institute and Maryland Judiciary, 'What works in District Court Day of Mediation: Effectiveness of Various Mediation Strategies on Short, and Long-Term Outcomes' (Administrative Office of the Courts, 2016).

100 Thomas Stipanowich, 'The International Evolution of Mediation: Call for Dialogue and Deliberation' (2015)

46 Victoria University of Wellington Law Review 1191, 1211.

101 Lillian Corbin, Paula Baron \& Judy Gutman, 'ADR Zealots, Adjudicative Romantics and everything in between: lawyers in mediations' (2015) 38(2) UNSW Law Journal 492, 503; See also Paula Baron, 'Throwing Babies out with the Bathwater - Adversarialism ADR and the Way Forward' (2014) 40(2) Monash University Law Review 283.

102 Olivia Rundle, 'Lawyers perspectives on what is court-connected mediation for?' (2013) 20(1) International Journal of The Legal Profession 33, 52.

${ }^{103}$ A study found that the presence of attorneys had a negative impact on the ability of parties to reach a reconciliation in their business relationship: Jean Poitras, Arnaud Stimec and Jean-Francois Roberge, 'The Negative Impact of Attorneys on Mediation Outcomes: A Myth or a Reality?' (2010) 26(1) Negotiation Journal 9, 18-19.
} 
The potential for affording greater prominence to the role of lawyers is especially troubling in the context of international commercial disputes. It has been argued that cross border commercial mediation is already more legalistic in nature than its domestic counterpart countering some of its inherent appeal. Mason, for example, has described international commercial mediation as one in which US companies bring more lawyers to than domestic mediation. ${ }^{104}$ Similarly, Strong has noted that 'savings of time and money may be even less likely to occur in international commercial matters [than domestic mediation], where there is a tendency for counsel to conduct mediations like "mini arbitrations". 105

Strong's empirical data suggests that parties are attracted to mediation in the cross-border context due to cost and time savings, as well as a desire for a more satisfactory process. ${ }^{106}$ The recent Global Pound Conference research also points to users seeking out more collaborative, efficient approaches to dispute resolution. ${ }^{107}$ It would be disappointing that if in dealing with the perceived problem of enforceability, the promise of mediation's qualitative benefits is lost as more adversarial behaviour is supported through the increased prominence of lawyers in the process.

\section{Expediting mediation}

\subsection{Barriers to international commercial mediation uptake}

In thinking about what measures might help expedite international commercial mediation, it is worth recalling the principal reasons why respondents to Strong's survey indicated that they

\footnotetext{
104 Paul Mason, 'What's Brewing in the International Commercial Mediation Process' (2011) 66(1) Dispute Resolution Journal 64, 68.

105 Shirley Strong, 'Beyond International Commercial Arbitration? The Promise of International Commercial Mediation' (2014) 45 Washington University Journal of Law and Policy 11, 16.

106 Shirley Strong, 'Realizing Rationality: An Empirical Assessment of International Commercial Mediation' [2016] 73 Washington \& Lee Law Review 1973, 2031.

${ }^{107}$ Herbert Smith Freehills and PWC, 'Global Pound Conference Series: Global Trends and Regional Differences' (Global Pound Conference Series, 2018) 11.
} 
would decline use. For those with experience of cross-border mediation, the main explanations included the lack of parties' and counsel's experience with mediation, fears about revealing litigation/arbitration strategy within the mediation, and concerns over mediator quality. Those without experience primarily cited a cultural preference for litigation or arbitration. ${ }^{108}$ The attitudes of lawyers may be especially important. In the Global Pound Conference survey all stakeholder groups identified external legal advisors as the primary obstacle to change in commercial dispute resolution practice. ${ }^{109}$ In the same survey when lawyers (both external and in-house) were asked as to the most influential factors guiding their recommendations to parties about procedural options for commercial disputes, the most commonly cited reason was 'familiarity with the process'. ${ }^{110}$ The lack of lawyer unfamiliarity then may be a major factor in stifling development of international commercial mediation.

These findings tally with more general ideas that the poor uptake of mediation across a range of contexts in a large part may emanate from the prevailing negative attitudes of lawyers and potential end users. Lawyers' resistance to mediation is well documented. ${ }^{111}$ Such intransigence towards the process may emanate from ignorance and a lack of sophisticated appreciation of mediation, cultural dissonance or pecuniary interests. ${ }^{112}$ This is important because (as suggested by the Global Pound Conference findings above) lawyers often act as gatekeepers to clients' involvement in mediation. ${ }^{113}$ The winds are changing and clients, especially of the commercial variety, have of late become more powerful relative to their

\footnotetext{
108 S Strong, 'Realizing Rationality: An Empirical Assessment of International Commercial Mediation' [2016] 73 Washington \& Lee Law Review 1973, 2034.

109 Herbert Smith Freehills and PWC, 'Global Pound Conference Series: Global Trends and Regional Differences' (Global Pound Conference Series, 2018) 3.

${ }^{110}$ Herbert Smith Freehills and PWC, 'Global Pound Conference Series: Global Trends and Regional Differences' (Global Pound Conference Series, 2018) 3.

${ }^{111}$ For a comprehensive review, see: Bryan Clark, Lawyers and Mediation (Springer 2012) ch 2.

112 Bryan Clark, Lawyers and Mediation (Springer 2012) ch 2.

${ }^{113}$ For the classic treatment see: Douglas Rosenthal, Lawyer and Client: Who's in Charge? (Russell Sage Foundation 1974).
} 
external lawyers and are typically more concerned with exacting efficiency of approach in their dispute resolution processes. ${ }^{114}$ It may remain the case, however, that even sophisticated clients glean most of their knowledge of mediation and other dispute resolution processes from their lawyers. ${ }^{115}$ The mediation option may rarely be raised as a possible course of action by disputing parties themselves. ${ }^{116}$ It is also well known, however, that resistance to mediation may be a deep-seated phenomenon in the client base. ${ }^{117}$ In this, mediation may be a hard sell. It speaks of compromise at a time of conflict. It asks parties to put their trust in a third party who is not their champion and will not adjudicate. The process cannot guarantee an outcome.

\subsection{Dismantling the barriers}

For domestic mediation, many endeavours in different jurisdictions to overcome weak growth of the process have been court-led. ${ }^{118}$ Despite the fact that efforts to expedite development of cross-border mediation in the EU have also focused largely on court promotion endeavours, ${ }^{119}$ it is not likely that such measures will be especially effective given the lack of involvement of the courts in international cases. ${ }^{120}$ Other domestic measures mirror those that may help in the

\footnotetext{
114 Julie Macfarlane, The New Lawyer: How Clients are Transforming the Practice of Law ( $2^{\text {nd }}$ edn, UBC Press 2017) $138-139$.

115 J Lande, 'Getting the Faith: Why Business Lawyers and Executives Believe in Mediation' (2000) 5 Harv Negot L Rev 137, 196.

${ }^{116}$ See, for example, in the New Zealand context where it was noted that where client self-referral did arise, it was more likely to stem from the legal background of the client or where the client was a repeat player in mediation: Grant Morris and Amanda Lamb, 'Lawyers as Gatekeepers to Commercial Mediation in New Zealand' (Report, 2016) 14-15.

${ }^{117}$ See Craig McEwen 'Managing Corporate Disputing: Overcoming Barriers to the Effective Use of Mediation for Reducing the Cost and Time of Litigation' (1998) 14 Ohio State Journal on Dispute Resolution 1.

${ }^{118}$ See, for example: Felix Steffek and Hannes Unberath (eds), Regulating Dispute Resolution: ADR and Access to Justice at the Crossroads (Hart Publishing 2013) 157.

${ }^{119}$ Giuseppe De Palo and others, 'Rebooting the Mediation Directive: Assessing the Limited Impact of its Implementation and Proposing Measures to increase the Number of Mediations in the EU' (Study, European Parliament, Directorate-General for Internal Policies 2014).

120 There are exceptions, including, for example, the promotion of mediation in the UK Commercial Court, where the substantial portion of cases heard are of the cross-border nature, see: Judges of the Commercial Court in England and Wales(eds), 'The Commercial Court Guide' (10 ${ }^{\text {th }}$ edn, HM Courts \& Tribunals Service, 2017) para D8.9

<https://assets.publishing.service.gov.uk/government/uploads/system/uploads/attachment_data/file/672422 /The_Commercial_Court_Guide_new_10th_Edition_07.09.17.pdf > accessed 16 June 2020.
} 
international commercial context. Numerous national jurisdiction reports have grappled with promoting mediation, including how sophisticated and meaningful awareness in the client and lawyer base can be raised to help grow the process, as well as help provide assurances over matters such as quality of mediation provision. ${ }^{121}$

\subsubsection{Measures for Lawyers and Mediators}

Absent court-led initiatives to promote mediation and force the hand of lawyers in the crossborder context, professional obligations may play a part. Indeed, these already exist. For example, in the EU when lawyers are engaged in cross-border practice, they must act in accordance with the Code of Conduct for European Lawyers adopted by the Council of the Bars and Law Societies of the European Union. ${ }^{122}$ The Code provides that 'the lawyer should at all times strive to achieve the most cost-effective resolution to the client's dispute and should advise the client at appropriate stages as to the desirability of attempting a settlement and/or reference to alternative dispute resolution'. ${ }^{123}$

While education and training in mediation has grown enormously of late, there does exist some concerns regarding training standards and the diverse mediation practice norms found across jurisdictions. Linked to this issue is the fact that codes of practice for mediators vary significantly across different jurisdictions and that the use of sanctions applicable where codes are breached is patchy. ${ }^{124}$ It has also been argued that expertise in domestic mediation is not

\footnotetext{
${ }^{121}$ For a recent discussion of these issues in the UK context, see: Bryan Clark, 'Where now for ADR?' (2019) New Law Journal <https://www.newlawjournal.co.uk/content/where-now-for-adr> accessed 16 June 2020; Bryan Clark, 'Some Reflections on 'I Won't See You in Court' (2019) 2 Juridical Review 182.

${ }^{122}$ Council of Bars \& Law Societies of Europe, 'Charter of Core Principles of the European Legal Profession \& Code of Conduct for European Lawyers' (2019).

${ }^{123}$ Council of Bars \& Law Societies of Europe, 'Charter of Core Principles of the European Legal Profession \& Code of Conduct for European Lawyers' (2019) 15, para 3.7.1.

${ }^{124}$ See the discussion in Katia Fach Gomez, 'The Role of Mediation in International Commercial Disputes: Reflections on Some Technological, Ethical and Educational Challenges' (2019) Mediation in International
} 
necessarily a proxy for cross border mediation ability given the inherent complexity of the latter. ${ }^{125}$ Reed, for example, has argued that 'the harsh reality is that, without the proper training, a first-rate domestic mediator is not naturally a successful international mediator'.126 There may be therefore be room for the further development of international standards through organisations such as the IMI that has already made significant strides in this field. ${ }^{127}$

\section{$\underline{5.2 .2 \text { In-house lawyers and contractual clauses to mediate }}$}

The Global Pound Conference data suggests that in-house counsel may be key facilitators in adopting mediation and in bridging the gap between clients and external lawyers. ${ }^{128}$ Both their numbers and influence is rising. As Macfarlane has noted: 'the power and prestige of general counsel within any given corporation is greater now than ever before and reflects a desire to take control of outside legal fees and strategy'. ${ }^{129}$ In comparison to external lawyers, in-house counsel may have none of the economic incentives that may tempt them to pursue certain forms of dispute resolution for their own interests. Nonetheless, they do share a cultural heritage and educational development with their external peers which may result in mediation being resisted.

Commercial and Investment Disputes, Oxford University Press <https://dx.doi.org/10.2139/ssrn.3418648> accessed 16 June 2020.

${ }^{125}$ Lucy Reed, 'Utima Thule: Prospects for International Commercial Mediation' (2019) Nus Centre for International Law Research Paper No 19/03.

${ }^{126}$ Lucy Reed, 'Utima Thule: Prospects for International Commercial Mediation' (2019) Nus Centre for International Law Research Paper No 19/03 9, para 3.1.

${ }^{127}$ A detailed discussion of these issues is outside the scope of this Article but for an excellent discussion see: Katia Fach Gomez, 'The Role of Mediation in International Commercial Disputes: Reflections on Some Technological, Ethical and Educational Challenges' (2019) Mediation in International Commercial and Investment Disputes, Oxford University Press 14-19 <https://dx.doi.org/10.2139/ssrn.3418648> accessed 16 June 2020.

${ }^{128}$ Herbert Smith Freehills and PWC, 'Global Pound Conference Series: Global Trends and Regional Differences' (Global Pound Conference Series, 2018).

129 Julie Macfarlane, The New Lawyer: How Clients are Transforming the Practice of Law (2 ${ }^{\text {nd }}$ edn, UBC Press 2017). 
One particular area where inside counsel can make a difference is through contract formation. At present the bulk of international commercial matters that find their way into mediation arise by way of a relevant dispute resolution clause in a contract. ${ }^{130}$ As has been noted by Reed, '[t]he bottom line is that if in-house counsel are committed to saving time and resources with international commercial mediation, they must take the lead in drafting the necessary clauses into contracts, or instructing their external counsel to do so'. ${ }^{131}$ Queck and Lee point to the discussions at the Global Pound Conference in this regard: 'several Panelists... spoke about inserting multi-tiered dispute resolution clauses into commercial contracts as a way of encouraging the business practice of attempting non-adjudicative processes first before proceeding to more drastic adjudicative forums'. ${ }^{132}$

\section{$\underline{5.2 .3 \text { Publicity of benefits }}$}

Direct selling to the client base is essential. In this, better promotion of success stories, in a language that potential users and in-house counsel understand may help expedite use. ${ }^{133}$ Equally, providing better guidance as to what the mediation shall entail may also be important, especially given the diversity of practice that can be encountered and the different cultural needs of potential participants. In the EU cross-border context, Lack and Schonewille have pointed to the diversity of practice in mediation arising from different national cultures and preferences, thus rendering it an inherently nebulous concept. One solution they advocate to

\footnotetext{
${ }^{130}$ See: Paul Mason, 'What's Brewing in the International Commercial Mediation Process' (2011) 66(1) Dispute Resolution Journal 64, 68. The Singapore Convention itself, controversially, did not make provision for the uniform enforcement of agreements to mediate.

${ }^{131}$ Lucy Reed, 'Utima Thule: Prospects for International Commercial Mediation' (2019) Nus Centre for International Law Research Paper No 19/03, 9 para 3.2. We do accept here that promoting mediation in this fashion may inevitably continue to the increased juridficiation of mediation in that clauses may prescribe specific procedures for the mediation to follow. For example, jurisprudence in England and Wales points to the detailed procedural nature of such clauses required to ensure their enforceability, see: WAH (aka Alan Tang) $v$ Grant Thornton International Ltd [2012] EWCH 3198.

132 Dorcas Anderson and Joel Lee, 'The Global Pound Conference in Singapore: A Conversation on the Future of Dispute Resolution' [2016) AJM 70.

${ }^{133}$ Some useful case study examples can be found in: Anthony Connerty, 'ADR as a 'filter' mechanism: the use of ADR in the context of international disputes' (2013) 79(2) Arbitration 120, 128-133.
} 
help expedite cross-border commercial use is to educate parties as to the availability of the different species of the process so as to allow parties and their counsel to make an informed choice. $^{134}$

\section{Conclusion}

It is understandable that the measures introduced by the Singapore Convention might be seen by enthusiasts as some kind of panacea to transform the relatively stagnant nature of international commercial mediation into a success story. Significant effort has gone into producing this new instrument and the hopes of many seem firmly pinned on it.

For the reasons put forward in this article, in the authors' view this trust is misplaced, however. In terms of its slow growth, the authors recognise that international commercial mediation is generally more complex than its domestic counterpart and, as a result, presents a range of additional hurdles to be overcome. Such matters include the multiparty nature of many crossborder commercial arrangements, cultural ${ }^{135}$ and language barriers, and complex, multicontract arrangements. ${ }^{136}$ Hence the speed and relative cheapness that advocates promote to potential users in domestic mediation may be more illusory in the cross-border context. Faced with this reality, mediation may be perceived as a tougher ask. Nonetheless, the promise of durability of outcome, preservation of relationships, flexible outcomes and process benefits

\footnotetext{
${ }^{134}$ Manon Schonewille and Jeremy Lack, 'Mediation in the European Union and Abroad: 60 States Divided by a Common Word?' in Manon Schonewille and Fred Schonewille (eds) The Variegated Landscape of Mediation: A Comparative Study of Mediation Regulation and Practices in Europe and the World (Eleven International Publishing, The Hague, 2013) 20-21.

${ }^{135}$ For a lucid examination of the potential problems of the traditional 'western' model of mediation in Asian jurisdictions such as Singapore, see Joel Lee, 'Culture and its Importance in Mediation' (2016) 16(2) Pepperdine Dispute Resolution Law Journal 317. See also Laurence Boulle, 'International Enforceability of Mediated Settlement Agreements: Developing the Conceptual Framework' (2014) 7 Contemporary Asia Arbitration Journal 35, 52-53.

${ }^{136}$ See S Strong, 'Beyond International Commercial Arbitration? The Promise of International Commercial Mediation' (2014) 45 Washington Journal of Law and Policy 11, 18-24; Lucy Reed, 'Utima Thule: Prospects for International Commercial Mediation' (2019) Nus Centre for International Law Research Paper No 19/03, para 2.1.
} 
remain. Further measures do need to be taken to unlock the potential fruits of mediation in the international commercial context. In the authors' view, however, tackling the perceived enforceability problem is not one of them. Indeed, there is a danger that the rush to embrace the Convention may lead to an undermining of international commercial mediation's essential attributes with the process all the poorer for it. 